\title{
Abdominal Wall Reconstruction-Diagnostic and Therapeutic Algorithm
}

\author{
Adrian PELINARU' ${ }^{1}$, Andreea GROSU-BULARDA ${ }^{\top}$, Carmen Ioana MOCANU', Razvan Nicolae \\ TEODOREANU ${ }^{1,2}$, Sabina GRAMA ${ }^{1}$, Tiberiu Paul NEAGU ${ }^{1,2}$, Serban ARGHIR POPESCU ${ }^{1,2}$, Ioan LASCAR ${ }^{1,2}$
}

\begin{abstract}
Due to its complex structure, the abdominal wall is vital as it serves to protect the internal organs, maintain the upright position and regulate the intraabdominal pressure. Complex abdominal defects are a major health problem, with challenging treatment, many complications and risks. It is not a completely elucidated pathology as there is no consensus in literature regarding the definition and classification. Although there are various reconstruction techniques, there is no sistematic protocol in literature that allows the surgeon to choose the best treatment suitable for each patient. Therefore, the first step to manage these patients is a carefull assesment of the patient background and only after that, a complete analysis of the actual wound should be made. Second step is appropriate abdominal wall closure. After the analysis of current data from international literature, we identified a decision-making algorithm to offer guidance in surgical management in order to obtain an optimal functional outcome. The foundation of the algorithm is the idea of gradually improving the local tissue status, in order to deal with a clean wound as much as possible. This way, the success rate of the surgical reconstruction improves.
\end{abstract}

Keywords: abdominal wall, defects, reconstruction, risk factors.

\section{Rezumat}

Peretele abdominal are o structură complexă din punct de vedere anatomic motiv pentru care lipsa integrității acestuia este incompatibilă cu desfășurarea în condiții de normalitate a activităților zilnice și în unele situații este chiar incompatibilă cu viața. Principalele funcții ale peretelui abdominal sunt protejarea viscerelor abdominale, stabilizarea presiunii intraabdominale, reglarea respirației, defecației, micțiunii și participarea activă la menținerea ortostatismului. Existența defectelor complexe de perete abdominal anulează una sau mai multe dintre aceste roluri motiv pentru care restabilirea lor devine extrem de dificilă. Nu există până în prezent o definiție clară și unanim acceptată a defectelor complexe de perete abdominal și nici un algoritm de tratament, cu toate că există numeroase posibilități reconstructive. Considerăm că un pas important spre a oferi un tratament centrat pe pacient îl constituie o evaluare corectă și exhaustivă a istoricului pacientului, dar și a statusului actual al plăgii în sine. Următorul pas îl constituie acoperirea defectului, motiv pentru care propunem un algoritm decizional care să ghideze chirurgul reconstructiv. Raționamentul algoritmului propus se bazează pe îmbunătățirea graduală a factorilor locali ai leziunii în vederea creșterii ratei de succes a procedeelor reconstructive aplicate.

Cuvinte cheie: perete abdominal, defecte, reconstrucție, factori de risc.

${ }^{1}$ Clinic of Plastic Surgery, Aesthetic and Reconstructive Microsurgery, Clinical Emergency Hospital, Bucharest, Romania 2 "Carol Davila" University of Medicine and Pharmacy, Bucharest, Romania

\section{Corresponding author:}

Andreea GROSU-BULARDA, Clinical Emergency Hospital,

$8^{\text {th }}$ Floreasca Avenue, Bucharest, Romania.

E-mail: andreeabularda@gmail.com 


\section{INTRODUCTION}

Due to its complex structure, the abdominal wall is vital as it serves to protect the internal organs, maintain the upright position and regulate the intraabdominal pressure. The last function mentioned allows the performance of certain actions that require the execution of Valsalva, such as defecation, urination, coughing and vomiting ${ }^{1}$. Some authors also suggest that the integrity of the abdominal wall is related to satiety and patients with abdominal wall defects are prone to gain weight ${ }^{2}$. Up to $20 \%$ of the patients that had elective median laparotomy develop an incisional hernia. There are several risk factors for incisional hernia formation such as wound infection, immunosupression, extreme obesity, age, malnutrition, multiple abdominal surgery, EhlersDanlos syndrome or aneurysmal disease ${ }^{3}$. Aging of the population, increase of diabetes rate and obesity, increase of abdominal cancer survival rate and the progress of medicine and patient-centered treatment are factors that lead to the annual increase in the number of patients with complex abdominal wall defects. Considering this, we believe that a more detailed study of this pathology is important and for start there are a few goals to achieve: establish a consensual definition, elaborate a classification and create a reconstruction algorithm.

\section{BACKGROUND-ACTUAL STATE OF KNOWLEDGE IN COMPLEX ABDOMINAL DEFECT RECONSTRUCTION}

\begin{abstract}
Anatomy
The abdominal wall has a multilayered structure that comprises the skin, subcutaneous tissue, the fascial layer, abdominal muscles (five pairs of muscles), preperitoneal adipose tissue and peritoneum ${ }^{4}$. A good understanding of the abdominal wall structures along with its neurovascular anatomy is decisive for abdominall wall reconstruction.
\end{abstract}

\section{Definition of complex abdominal wall defect}

To date, there is no widley accepted definition of the complex abdominal wall defect. Analyzing existing literature data, we observed different approaches for abdominal wall defects evaluation, influenced by each center experience. For example, S J Mathes et al consider as the main particularity of a complex abdominal wall defect the failure of prior attempt at closure ${ }^{5}$ while A. Leppaniemi refers to the patients where simple repair of abdominal hernia is not possible due to large size of the defect ${ }^{6}$. Other authors consider as complex defect any abdominal defect that cannot be closed primary without tension ${ }^{7}$.

Although there is not a consensus on the definition there are some common features that are mentioned by all authors when describing a complex abdominal wall defect. These include a possible concomitant infection or a visceral fistula, multiple failed attempts of repair and lack of enough local skin to cover the defect. These defects are often a result of trauma, including burn injury, radiation necrosis, local infection with multiple excisional debridement, or tumor resection ${ }^{5}$. There are multiple tumors that can occur on the abdominal wall, but the most common one is desmoid tumor. Although the tumor is histologically benign, it is very invasive in the local tissue and has a high rate of recurrence (40\%-50\%) thus leading to multiple resections. The most common malignant tumors of the abdominal wall are sarcomas and beside aggressive resection, the treatment is also completed by radiation therapy which affects even more local structures ${ }^{1}$. Regarding that the complex abdominal wall defects are often large both in diameter and depth, they may affect multiple layers of the abdominal wall and result in complex neuromuscular deformities or evisceration with loss of domain.

The Italian Consensus Conference on "Complex abdominal wall management" held in June 2015 has divided the definition in two major entities, one for emergency and one for chronic patients. The definition of complex abdomen in emergency referes to the situation where there is an increased risk for occurence of compartment syndrome, early reintervention or suture dehiscence. They define the complex abdomen in elective surgery when there is at least one of the following situations: loss of domain grater than 20\%, surgical wound class III or IV infection, non-healing wound, the presence of fistula, recurrent hernia, previous mesh infection, full thickness wall defects, necessity of intraperitoneal mesh extraction ${ }^{8}$.

\section{Classification of complex abdominal wall defects}

Most of current data in literature reffer to classification of complex abdominal wall hernia, but there is no clarification on how to group complex abdominal wall defects, considering that there are so may variables to be taken into consideration. Currently the available clas- 

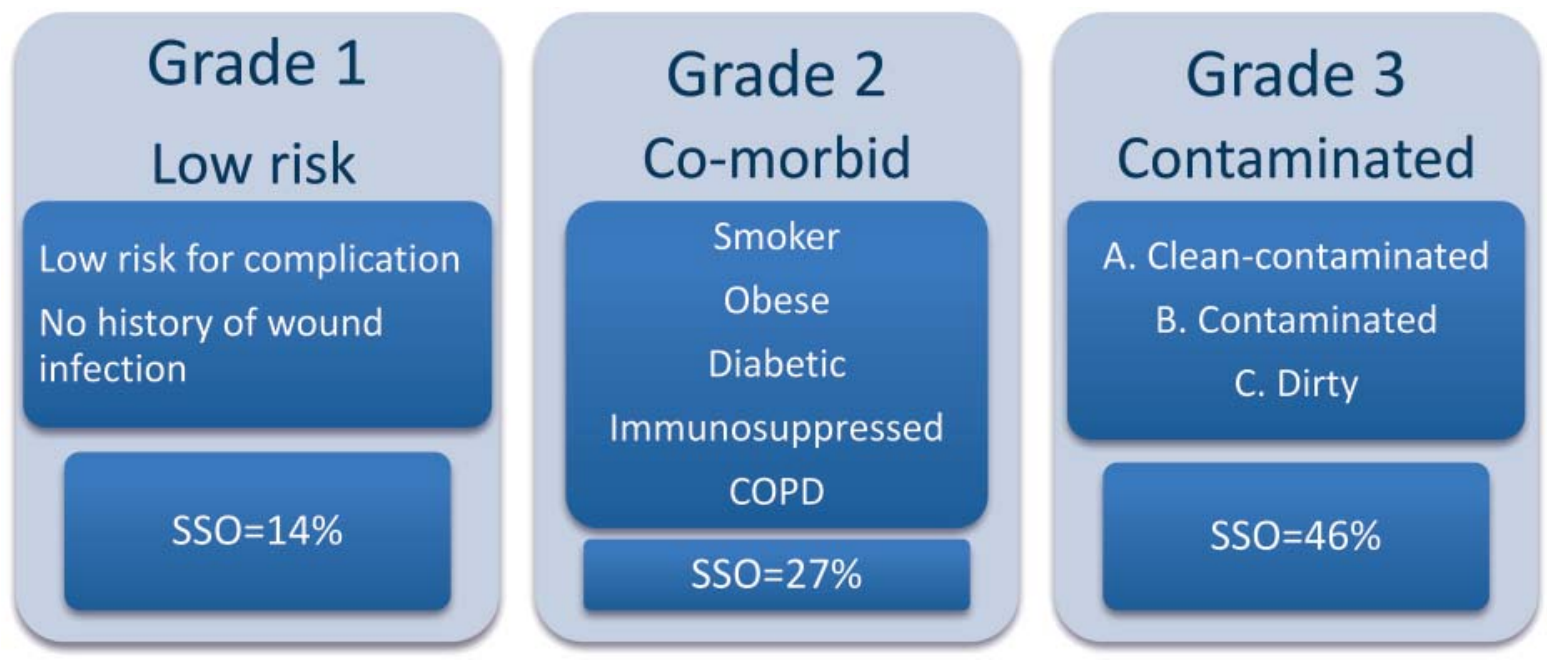

Figure 1. SSO =surgical site occurrence of infection, seroma, dehiscence, enterocutaneous fistula.

sification for surgeons is the „Ventral Hernia Working Group“ grading sistem for risk of complications at the surgical site. The last modified VHWG grading sistem was updated since 2012 (Figure 1$)^{9}$.

$\mathrm{S} J$ Mathes et al. have classified the abdominal wall defects according to their location into zones $1 \mathrm{~A}$ (upper midline), 1B (lower midline), 2 (upper quadrant), 3 (lower quadrant) and according to local tissue quality into Type I (stable coverage with skin over hernia defect) and Type II ( unstable or abscence of skin coverage over defect) (Figure 2$)^{5}$.

According to N J Slater et al complex hernia patients can be grouped in four categories: size and location, contamination, patient history and risk factor, clinical presentation. Each of these variables can be divided in three severity classes: Minor, Moderate, Major. This classification was created to guide the surgical management and assess the financial costs of $\mathrm{it}^{10}$.

\section{Goals of abdominal wall reconstruction}

The goals to be achieved in abdominal wall reconstruction may vary depending whether the surgery is perfomed in emergency or in elective fashion. For emergency surgery, the main goal is rather to relief incarceration or strangulation of viscera ${ }^{11}$. For patients without such critical status, the surgeon has to obtain a strong and dynamic abdominal wall, to prevent recurrence and to achieve a satisfactory esthetic appearance. The ultimate

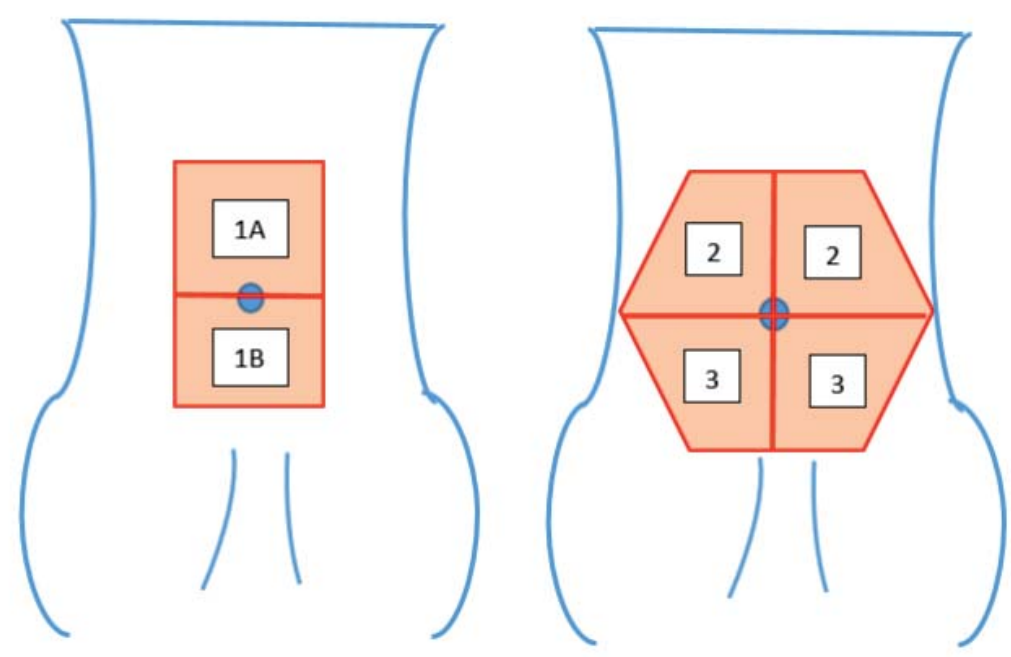

Figure 2. Reconstructive abdominal zones- $1 \mathrm{~A}=$ upper midline, $1 \mathrm{~B}=$ lower midline, $2=$ upper quadrant, $3=$ lower quadrant. 
goal of all these is to increase the quality of life ${ }^{12}$ and for that the surgeon must always choose the best treatment option for each patient.

There are many closure techniques available to the reconstructive surgeon. Choosing the surgical approach should always follow the reconstructive ladder, starting with simple approach if possible and moving to more complicated ones as previous options fail or do not seem to be suitable from the beginning ${ }^{13}$.

A model of the reconstructive ladder can be the following (Figure 3) ${ }^{14}$.

\section{DIAGNOSTIC AND THERAPEUTIC ALGORITHM FOR EVALUATION AND TREATMENT OF PATIENTS WITH ABDOMINAL WALL DEFECTS}

Considering that choosing the best option for treatment of the complex abdominal wound defects is a real challenge, as there is no protocol yet for this pathology, we identified, after the analysis of current data from international literature- an algorithm that could guide the surgeon through decision making in order to obtain an optimal functional outcome (Figure 4).

\section{DISCUSSION}

Performing an effective abdominal wall reconstruction requires some basic principles: Correct patient selection and optimization of risk factors, choosing the right procedure, preserve skin and subcutaneous tissue, careful postoperative management ${ }^{14}$.
In order to minimize the SSO (surgical site occurences - dehiscence, seroma, hematoma, skin necrosis, fistula, etc) and hernia reccurence, a careful prehabilitation must be done. In general, patients that are poor candidates for a surgical procedure should be delayed until the risk factors are assessed and the modifiable ones are optimized. The main risk factors for complications are obesity, infection, hernia size, smoking, chronic resipratory disease, poor wound healing, failure of previous reconstruction with mesh. There are two particular risk factors that are directly related to increased rate of reccurence. These are a BMI (body mass index) $>$ than $30 \mathrm{~kg} / \mathrm{m}^{2}$ and defect size $>8-10 \mathrm{~cm}$. Sauerland $\mathrm{S}$ et al. suggest that there is a $10 \%$ increase in hernia reccurence risk with every unit of $\mathrm{BMI}^{15}$. Many surgeons use a BMI equal to $40 \mathrm{~kg} / \mathrm{m}^{2}$ as a cutoff before declining elective abdominal wall reconstruction. At the opposite pole of obesity, protein malnutrition, mainly the lack of methionine and arginine, is associated with higher mortality ${ }^{16}$. Also, low albumine increases the risk of infection ${ }^{17}$. Poorly controlled diabetes is also a risk factor for SSO. Preoperatively, the level of glucose should be kept below $160 \mathrm{mg} / \mathrm{dL}$, otherwise the risk of infection and dehiscence is highly increased ${ }^{18}$. Smoking cessation should occur at least 4 weeks before and after surgery for a significantly decrease of infectious risk, as it is well known that tobacco decreases tissue perfusion ${ }^{19}$.

Treating complex abdominal wall defects may be very challenging for the reconstructive surgeon. In case of skin loss alone, the defect can be treated with skin graft, tissue exapnders or soft-tissue flaps. For myofas-

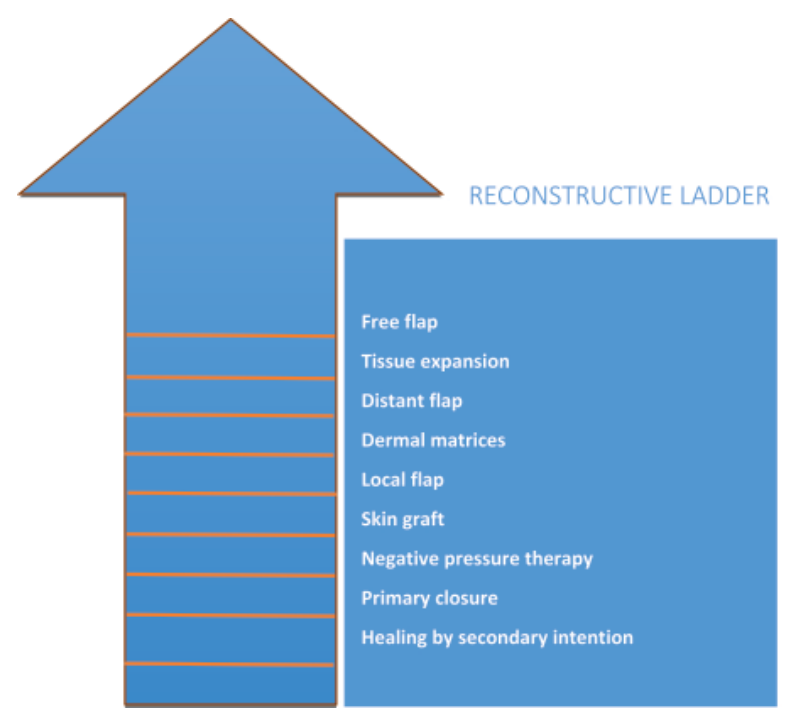

Figure 3. 

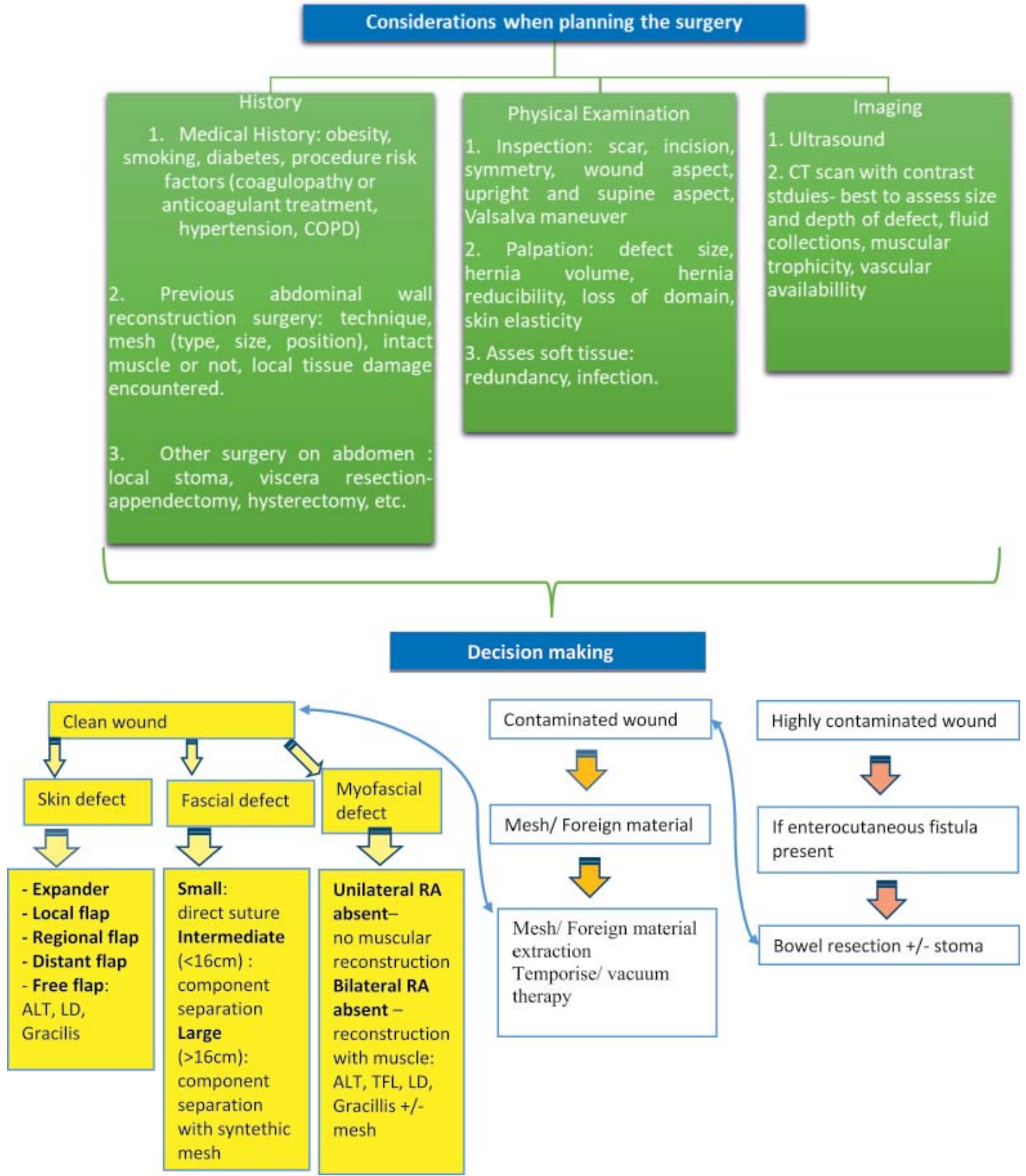

Figure 4. Proposed algorithm: $A L T=$ antero-lateral thigh flap, $L D=$ Latissimus dorsi flap, $R A=$ rectus abdominis muscle, $T F L=$ tensor fascia lata flap.

cial defects, all eforts must be done to primary close the fascia, after propper excision of non-viable tissue. This is mandatory in order to achieve a stable abdominal wall, that is able to resist strain and stress. If primary fascial closure is not possible, component separation should be performed ${ }^{20}$. For fascial defects larger than $16 \mathrm{~cm}$, bilateral component separation is required, often with a mesh reinforcement. Some surgeons constantly use mesh reinforcement even when primary fascial closure is possible as it is proven to lower the recurrence rate by up to $50 \%{ }^{21}$. Sometimes it is unvoidable to leave the fascia open due to trauma, vascular emergences or compartment syndrome, and a staged repair is needed. Usually a skin graft or a vacuum therapy can be applied to temporize the final repair ${ }^{6}$. Also, temporary abdominal closure with mesh and vacuum assisted therapy has been described ${ }^{22}$.

If there is a partial myofascial loss, a single rectus abdominis muscle is enough to reconstruct the abdominal wall, but if both muscles are absent a functional 
reconstruction has to be done with soft tissue flaps. For the upper two thirds of the abdomen, local flap options include the latissimus dorsi, internal oblique, external oblique, rectus abdominis, inferior epigastric perforator, and superior epigastric perforator flaps. Reconstruction of the lower two thirds of the abdomen with local flaps can be achieved with tensor fascie latae (TFL), rectus abdominis, vastus lateralis flaps, antero-lateral thigh (ALT) and gracillis flaps. Free tissue transfer is preferred when the motor function of the abdominal wall is severly altered. The best situation to use a free flap is when there is a full-thickness defect that comprises the upper third of the abdomen ${ }^{6}$. The best flaps suitable for microvascular reconstruction are ALT, TFL and rectus femoris flaps ${ }^{23}$.

It is often possible that due to severe traumatic injury, or wide tumoral resection, patients with complex defects of the abdominal wall also need a visceral transplantation. These are the ideal candidates for vascularized composite allotransplant of the abdominal wall. For now, this is also an ultimate solution when conventional treatment techniques are exhausted ${ }^{24}$. This technique provides immediate coverage of viscera. Levi et al described reconstructing the abdominal wall with partial abdominal wall transplants and five out of eight patients had a functioning and viable abdominal wall at a 23 months follow-up ${ }^{25}$. When abdominal wall transplantation is combined with organ transplantation it is possible that the morbidity rate is the lowest on long term follow-up, due to the fact that additional immunosuppression is not needed.

\section{References}

1. Varacallo M, Scharbach S, Al-Dhahir MA. Anatomy, Anterolateral Abdominal Wall Muscles. In: StatPearls [Internet]. Treasure Island (FL): StatPearls Publishing; 2020 Jan-. Available from: https://www.ncbi.nlm.nih.gov/books/NBK470334/

2. Hope WW, Abdul W, Winters R. Abdominal Wall Reconstruction. In: StatPearls [Internet]. Treasure Island (FL): StatPearls Publishing; 2020 Jan-. Available from: https://www.ncbi.nlm.nih. gov/books/NBK431108

3. René H. Fortelny. Abdominal Wall Closure in Elective Midline Laparotomy: The Current Recommendations. Front Surg. 2018; 5: 34.

4. Seeras K, Qasawa RN, Prakash S. Anatomy, Abdomen and Pelvis, Anterolateral Abdominal Wall . StatPearls Publishing; Treasure Island (FL): Mar 3, 2020

5. Mathes SJ, Steinwald PM, Foster RD, Hoffman WY, Anthony JP. Complex abdominal wall reconstruction: a comparison of flap and mesh closure. Ann Surg. 2000;232(4):586-596.

6. Leppäniemi A, Tukiainen E. Reconstruction of Complex Abdominal Wall Defects. Scand J Surg. 2013;102(1):14-9

7. Bath AS, Patnaik PK, Bhandari PS. Reconstruction of Complex Abdominal Wall Defects. Med J Armed Forces India. 2007; 63(2):123-126.
When the defect is complicated by an enterocutaneous fistula, the first step is to treat the infectious source and prevent sepsis ${ }^{26}$. This often requires an intestinal repair, gastro-intestinal diversion and formation of an ostomy, with the disadvantage that the site of ostomy may interfere with potential options of local soft tissue flaps. Unfortunately, this a procedure indicated in order to convert a complicated wound to contaminated and further to clean wound for a future abdominal closure ${ }^{23}$.

\section{CONCLUSIONS}

Complex abdominal defects are a major health problem and treating is really challenging with many pifalls and risks. It is not a completely elucidated patho$\operatorname{logy}$ as there is nor consensus in literature regarding the definition and classification, neither an approved protocol of treatment. The method of abdominal wall reconstruction needs to be individually tailored and that is why we consider that the algorithm proposed can be useful for planning and decision making, in order to achieve an optimal functional outcome.

Compliance with ethics requirements: The authors declare no conflict of interest regarding this article. The authors declare that all the procedures and experiments of this study respect the ethical standards in the Helsinki Declaration of 1975, as revised in 2008(5), as well as the national law. Informed consent was obtained from all the patients included in the study.

8. Piccoli M, Agresta F, Attinà GM, Amabile D, Marchi D; "Complex abdominal wall study" Italian Collaborative Group. "Complex abdominal wall" management: evidence-based guidelines of the Italian Consensus Conference. Updates Surg. 2019;71(2):255272. doi:10.1007/s13304-018-0577-6

9. Kanters AE, Krpata DM, Blatnik JA, Novitsky YM, Rosen MJ. Modified hernia grading scale to stratify surgical site occurrence after open ventral hernia repairs. J Am Coll Surg. 2012;215(6):787-793. doi:10.1016/j.jamcollsurg.2012.08.012

10. Slater NJ, Montgomery A, Berrevoet F, et al. Criteria for definition of a complex abdominal wall hernia. Hernia. 2014;18(1):7-17.

11. Yang XF, Liu JL, Acute incarcerated external abdominal hernia. Ann Transl Med. 2014 Nov; 2(11): 110

12. Sosin M, Patel KM, Albino FP, Nahabedian MY, Bhanot P. A patient-centered appraisal of outcomes following abdominal wall reconstruction: a systematic review of the current literature. Plast Reconstr Surg. 2014;133(2):408-418.

13. Simman R. Wound closure and the reconstructive ladder in plastic surgery. J Am Col Certif Wound Spec. 2009;1 (1):6-11.

14. Khansa I, Janis JE. The 4 Principles of Complex Abdominal Wall Reconstruction. Plast Reconstr Surg Glob Open. 2019;7(12):e2549. Published 2019 Dec 26. doi:10.1097/GOX 0000000000002549 
15. Sauerland S, Korenkov M., Kleinen T. et al. Obesity is a risk factor for recurrence after incisional hernia repair. Hernia 2004; (8), 42-46.

16. Kudsk KA, Tolley EA, DeWitt RC, et al. Preoperative albumin and surgical site identify surgical risk for major postoperative complications. JPEN J Parenter Enteral Nutr. 2003;27(1):1-9.

17. Engelman DT, Adams DH, Byrne JG, et al. Impact of body mass index and albumin on morbidity and mortality after cardiac surgery. J Thorac Cardiovasc Surg. 1999;118(5):866-873.

18. Endara M, Masden D, Goldstein J, Gondek S, Steinberg J, Attinger $\mathrm{C}$. The role of chronic and perioperative glucose management in high-risk surgical closures: a case for tighter glycemic control. Plast Reconstr Surg. 2013;132(4):996-1004.

19. Møller AM, Villebro N, Pedersen T, Tønnesen H. Effect of preoperative smoking intervention on postoperative complications: a randomised clinical trial. Lancet. 2002;359(9301):114-117.

20. Booth JH, Garvey PB, Baumann DP, et al. Primary fascial closure with mesh reinforcement is superior to bridged mesh repair for abdominal wall reconstruction. J Am Coll Surg. 2013; 217(6):999-1009.
21. Luijendijk RW, Hop WC, van den Tol MP, et al. A comparison of suture repair with mesh repair for incisional hernia. $N$ Engl $J$ Med. 2000;343(6):392-398.

22. Petersson U, Acosta S, Björck M: Vacuum-assisted wound closure and mesh-mediated fascial traction-a novel technique for late closure of the open abdomen. World J Surg 2007; 31:21332137

23. Patel NG, Ratanshi I, Buchel EW. The Best of Abdominal Wall Reconstruction. Plast Reconstr Surg. 2018 Jan;141(1):113e$136 e$.

24. Light D, Kundu N, Djohan R, et al. Total Abdominal Wall Transplantation: An Anatomical Study and Classification System. Plast Reconstr Surg. 2017;139(6):1466-1473

25. Levi DM, Tzakis AG, Kato T, et al. Transplantation of the abdominal wall. Lancet 2003;361:2173-2176.

26. Leppäniemi A: The hostile abdomen - a systematic approach to a complex problem. Scand J Surg 2008;97: 218-219. 
